\title{
Research Concerning the Fighting of Polystigma rubrum Fungi under the Climate Conditions of Somcuta Mare Area
}

\author{
Lucia MIHALESCU ${ }^{1 *}$, Monica MARIAN ${ }^{1}$, Stela JELEA ${ }^{1}$, Flavia POP ${ }^{1}$, Aurel MAXIM² ${ }^{2}$ Zorica VOŞGAN ${ }^{1}$ \\ ${ }^{1}$ Technical University of Cluj-Napoca, North University Center of Baia Mare, 76 Victoriei St., 430122 \\ Baia Mare, Romania. \\ ${ }^{2}$ University of Agricultural Sciences and Veterinary Medicine, Cluj-Napoca, 3-5 Calea Manastur, 400372 \\ Cluj-Napoca, Romania \\ *corresponding author: luciamihalescu@yahoo.com
}

Bulletin UASVM series Agriculture 76(2) / 2019

Print ISSN 1843-5246; Electronic ISSN 1843-5386

DOI:10.15835/buasvmcn-agr: 2019.0013

\begin{abstract}
In this study, our goal was to survey the influence of the climate conditions, the behavior of the Centenar and Anna Spath varieties on the attack of the Polystigma rubrum fungi during the two experimental years (2013, 2014), in order to make recommendations for new plantations. Nine fungicides were tested, being determined their biologic efficiency, in order to identify the most efficient products. The experimental research was performed during 2013 and 2014, in a fruit tree farm belonging to SC Pomicola SA trade company in Somcuta Mare, Maramures county. The attack was calculated by determining the frequency, intensity and the attack degree. The agrometeorological data were recorded using the AgroExpert system, for surveying the biology of fungi. The linear-interrupted laying method was used, each made up of 5 plants/variant in three repetitions/product. The biologic efficiency of the tested products was lower at the Anna Spath variety than at the Centenar variety due to its sensitivity; the recommended products: Folicur Solo 250EW, Dithane M45 and Syllit 400 SC were the most efficient in the fungi combating.
\end{abstract}

Keywords: attack, fungicides, red stain, variety

\section{Introduction}

The climate conditions favor in plum trees the development of rust type fungi, mycotic and bacterial trickles, monilinia, etc (Oroian et al., 2006). One of them, the red staining affecting its leaves is extremely damaging: (Polystigma rubrum), occurring especially where phytoprotection treatments are not performed (Parvu, 2010). The territory of Romania is falling in the temperate climate continental area, that favors the development of plum tree growing, and an important technological chain link is the combating of the pathogens which affect the production quality and quantity (Ghena et al., 1977).

According to research conducted by Mitre et al., 2015, the cultivation of varieties resistant to diseases is the main objective for growers of fruit trees.

Variation of carbohydrate content in all plum cultivars shows a low content in the attacked fruits, illustrating the influence of the attack of the fungus Polystigma rubrum on nutritional value of fruits (Labusca et al., 2011).

The fruits of this variety is an important source of income, being a valuable food andindustry 
Table 1. The efficiency of some tested fungicides on the Centenar and Anna Spath varieties in 2013

\begin{tabular}{|c|c|c|c|c|c|c|c|}
\hline \multirow{3}{*}{ No. } & \multirow{3}{*}{ Product } & \multirow[t]{3}{*}{ Concentration \% } & \multicolumn{5}{|c|}{ Attack on leaves } \\
\hline & & & \multicolumn{2}{|c|}{ Frequency $\%$} & \multicolumn{2}{|c|}{ Intensity 1-6 } & \\
\hline & & & Centenar & Anna Spath & Centenar & Anna Spath & \\
\hline 1 & Alcupral $50 \mathrm{PU}$ & 0.2 & & 0.3 & 1.5 & 1 & 2 \\
\hline 2 & $\begin{array}{c}\text { Bouille Bordelaise } \\
\text { TIP "MIF" }\end{array}$ & 0.5 & & 0.5 & 1.2 & 1 & 2 \\
\hline 3 & Delan 700 WDG & 0.05 & & 0.3 & 2.3 & 1 & 2 \\
\hline 4 & Bravo 500 SC & 0.2 & & 3.0 & 1.3 & 3 & 2 \\
\hline 5 & Folpan 80 WDG & 0.2 & & 1.5 & 1.7 & 2 & 4 \\
\hline 6 & Dithane M 45 & 0.2 & & 0.2 & 1.0 & 1 & 1 \\
\hline 7 & Signum & 0.05 & & 0.3 & 1.2 & 1 & 2 \\
\hline 8 & Syllit $400 \mathrm{SC}$ & 0.13 & & 0.1 & 1.0 & 1 & 1 \\
\hline 9 & Folicur Solo $250 \mathrm{EW}$ & $0.075-0.1$ & & 0.1 & 1.1 & 1 & 1 \\
\hline & & Intensity & & & & $\begin{array}{c}1-3 \\
\text { Dominates } 1\end{array}$ & $\begin{array}{c}1-4 \\
\text { Dominates } \\
2\end{array}$ \\
\hline & Control (untre & ated) & & & 30.3 & & \\
\hline
\end{tabular}

product (Parvu, 2002). Consumed as such, or prepared as juice, infusion, decoction, plum is recommended for the treatment of numerous disorders (Badescu et al., 1977). In the study of any disease, it must be taken the account of the interdependence of the factors that determine their appearance and evolution (Lupescu, 2005). It was found that all the actual plum varieties are susceptible of Polystigma rubrum (Minoiu and Lefter, 1987). Knowledge on the varieties resistance or sensitivity degree is important in the differential application of the reducing of the number of treatments, in the optimal efficiency conditions (Gradinaru and Istrate, 2004). The analysis of the resistance to fungal diseases of some plum varieties was carried out by Glišiæ et al., 2016, which showed that the resistance of some varieties influences the productivity.

Chemical products prove effective under the conditions of their rationale use, but their use without discernment leads to low and qualitatively impaired productions (Dobrota et al., 1991).

Based on the described considerations, the goal of our research was to survey the resistance, respectively the sensitivity of the varieties on the leaves red staining, as well as the testing of some fungicides, determining their biologic efficiency, to recommend the most efficient of them for the production.

\section{Materials and methods}

The experimental research was performed during 2013 and 2014, in a fruit tree farm belonging to SC Pomicola SA trade company in Somcuta Mare, Maramures county. The area of the plum tree plantation is of $15 \mathrm{ha}$, more than 30 years old. The existing plum tree varieties are: Centenar, Anna Spath, Stanley, Tuleutimpuriu, Tuleugras, Gras ameliorat. The plant protection products were tested on the Centenar and Anna Spath varieties. The applied agrotechnics: tilling land on rows and grassland between trees. Nine fungicides that had been homologated for the combating of the red staining of plum tree leaveswere tested during 2013 , on the two studied varieties, calculating the frequency and intensity of the attack on leaves.

The tests continued also in 2014, to confirm whether the same ranking of products is as effective as in the previous year, and in the same time the calculation of the biologic efficiency was carried out for three selected fungicides out the tested 9 fungicides.

In order to carry out the experiments, we had 5 trees/variant in three repetitions/ product. During the observation period 3 trees were considered, and the trees on the edge were upheld as protection lane between the variants, as untreated control plants.

In order to achieve the proposed goals, the agrometeorological data were recorded using the AgroExpert system, for surveying the biology of fungi to carry out the treatments. The linearinterrupted laying method was used, and the attack was figured by the values of the frequency (F\%) and intensity (I\%). The assessment of the biologic efficiency of the tested products was 
Table 2. The efficiency of some tested fungicides on the Centenar and Anna Spath varieties in 2014

\begin{tabular}{|c|c|c|c|c|c|c|}
\hline \multirow{2}{*}{ No. } & \multirow{2}{*}{ Product } & \multirow{2}{*}{ Concentration $\%$} & \multicolumn{3}{|c|}{ Attack on leaves } & \\
\hline & & & \multicolumn{2}{|c|}{ Frequency \% } & \multicolumn{2}{|c|}{ Intensity 1-6 } \\
\hline 1 & Alcupral 50 PU & 0.2 & 0.2 & 1.3 & 1 & 2 \\
\hline 2 & $\begin{array}{l}\text { Bouille Bordelaise } \\
\text { TIP "MIF" }\end{array}$ & 0.5 & 0.4 & 0.8 & 1 & 2 \\
\hline 3 & Delan 700 WDG & 0.05 & 0.2 & 2.2 & 2 & 3 \\
\hline 4 & Bravo 500 SC & 0.2 & 2.0 & 1.2 & 2 & 2 \\
\hline 5 & Folpan 80 WDG & 0.2 & 1.3 & 1.5 & 1.5 & 1 \\
\hline 6 & Dithane M 45 & 0.2 & 0.1 & 0.5 & 1 & 1 \\
\hline 7 & Signum & 0.05 & 0.2 & 0.9 & 1 & 1 \\
\hline 8 & Syllit 400 SC & 0.13 & 0.1 & 0.6 & 1 & 1 \\
\hline 9 & Folicur Solo 250 EW & $0.075-0.1$ & 0.1 & 0.7 & 1 & 1 \\
\hline \multicolumn{3}{|c|}{ Intensity } & & & $\begin{array}{c}1-2 \\
\text { Dominates } 1\end{array}$ & $\begin{array}{c}1-3 \\
\text { Dominates } 1\end{array}$ \\
\hline & Control (untr & & 20.8 & 28.0 & & \\
\hline
\end{tabular}

Table 3. The biologic efficiency of the treatments against Polystigma rubrum fungi for the Centenar variety in 2014

\begin{tabular}{ccccc}
\hline Experimental variant & Concentration \% & Attack frequency \% & Attack intensity \% & Biologic efficiency \% \\
\hline Control & - & 78.0 & 66.7 & - \\
\hline V1 Dithane M 45 & 0.2 & 28.5 & 9.0 & 86.5 \\
\hline V2 Syllit 400 SC & 0.13 & 30.0 & 10.5 & 84.3 \\
\hline V3 Folicur Solo 250 EW & 0.1 & 19.0 & 8.4 & 87.5 \\
\hline
\end{tabular}

carried out by observing the techniques compared to the control.

\section{Results and Discussion}

In the conditions of 2013, when in the first part of the year there were moderate temperatures and many precipitations all over the spring summer period, favored the fungi occurrence on the new vegetative organs such as: leaves/sprouts, a medium to strong attack especially on the most sensitive tested variety was recorded.

As for the tests of the 9 fungicides on the Centemir and Anna Spath varieties during 2013 we note very good results for the products Folicur Solo 250EW, Syllit 400SC and Dithane M45 in the Table 1, healthy foliage, healthy sprouts with annual growth and high production of quality fruits resulted.

At the Centenar variety, after the treatments with Folicur Solo 250EW, Syllit 400SC and Dithane M45, the frequency of the attack on leaves was comprised in the interval of $0.1-0.2 \%$, unlike the other tested products where it was comprised in the interval of $0.3-1.5 \%$.
As for the Anna Spath variety, the most efficient products proved to be Syllit 400SC and Dithane M45, where the attack on leaves had a frequency of $1.0 \%$ and Folicur Solo 250EC with 1.1\%.The ranking was the same as for the previous variety, but unlike it, the values of the attack frequency were higher due to the sensitivity of the second variety.

Testing of fungicides on plum varieties were performed in Slovakia (Macuhova and Briatkova, 1991), where the influence of humidity on the intensity of the attack of Polystigma rubrum was highlighted.

The experimental year 2014, under climate conditions of high amplitudes of temperature, mostly recorded during the first period of vegetation, was not favorable for the fungi development, as the recorded precipitations were half of the multiannual average, and their distribution over the period of vegetation was not uniform. Table 2 shows a decrease of the frequency of the attack on leaves at all the 9 tested products, for both varieties.

The best results were recorded for the products Dithane M45, Syllit 400SC and Folicur 
Table 4. The biologic efficiency of the treatments against Polystigma rubrum fungi for the Anna Spathvariety in 2014

\begin{tabular}{ccccc}
\hline Experimental variant & Concentration \% & Attack frequency $\%$ & Attack intensity $\%$ & Biologic efficiency $\%$ \\
\hline Control & - & 85.0 & 70.0 & - \\
\hline V1 DithaneM 45 & 0.2 & 30.5 & 10.4 & 85.2 \\
\hline V2 Syllit 400 SC & 0.13 & 32.1 & 12.6 & 82.0 \\
\hline V3 Folicur Solo 250 EW & 0.1 & 20.8 & 9.2 & 86.5 \\
\hline
\end{tabular}

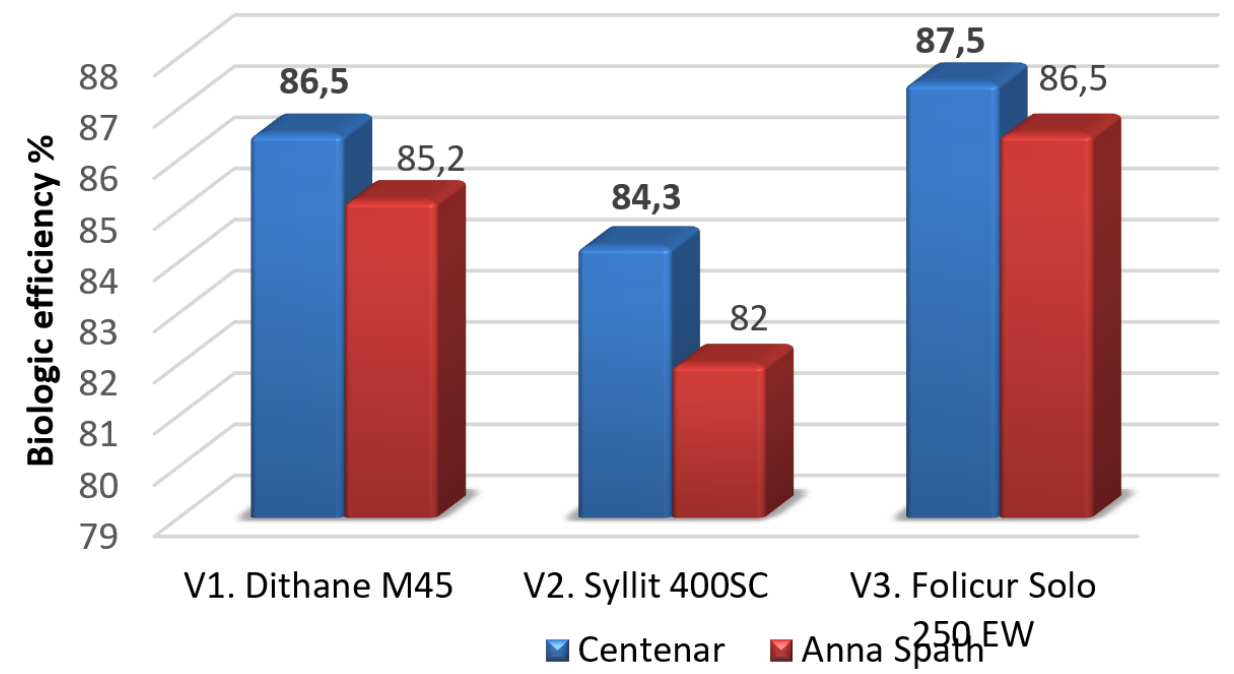

Figure 1. Biologic efficiency of the 3 products for the Anna Spath and Centenar variety in 2014.

Solo 250EC, where, for the Centenar variety the frequency of the attack on leaves was $0.1 \%$, and for the Anna Spath variety $0.5-0.7 \%$. The attack was a little bit higher than for the second variety, due to its higher sensitivity.

Similar research was carried out by Molnar et al. 2018 in two experimental years on four varieties of plum, which found that the weather conditions had an influence on the development of fungus Polystigma rubrum.

The research continued by calculating the biologic efficiency of the three products, which proved good results during the two experimental years (Tables 3 and 4 ).

At the Centenar variety, the intensity of the attack on leaves had values of $8.4-10.5 \%$. Thus, from $66.7 \%$ in the case of the untreated control to 8.4 , with a biologic efficiency of $87.5 \%$ in the case of the variant V3 - Folicur Solo 250EC. In the case of the variants V1 and V2 the biologic efficiency is situated between 84.3 and $86.5 \%$, which are very good results, and this iswhy the three variants are recommended to be used in the scheme of combating Polystima rubrum fungi.
In Table 4, we note that the biologic efficiency of the tested products for the Anna Spath variety is lower due to its higher sensitivity.

In Fig. 1, it is presented the biologic efficiency of the 3 products for the Anna Spath and Centenar variety in 2014.

We note that the product with the highest biologic efficiency wasFolicur Solo 250EC for both varieties. The Centenar variety shows a higher efficiency, proving that it is lesser vulnerable to Polystima rubrum.

Also,Labuscaet al.(2011), showed that the fungus Polystigma rubrum has a different degree of attack depending on the sugar content of the variety.

\section{Conclusion}

Regarding the combating of the plum leaves red stain (Polystima rubrum), in the two experimental years, the climate conditions differently influenced the attack degree.Important fungi attack on both studied varieties were recorded in 2013, due to the high temperatures, on the background of high atmospheric humidity,which created favorable 
development conditions, and the conditions of 2014 were less favorable to the attack.

Subsequent to the assessment of the experimental data, it was found that the Centenar variety showed outstanding resistance against the fungus attack, and the Anna Spath variety proved vulnerable.

An important fact in the Polystigma rubrum attack limitation, is the growing of tolerant and resistant species, in our case, the Centenar species is the privileged one.Of the 9 tested fungicides, we have pointed out that the following products: Folicur Solo 250 EW, Ddithane M45 and Syllit 400 SC have had good results, as their biologic efficiency has been over $80 \%$.

Our results may be useful for small and big farmers, as we can recommend them the species with the best resistance for new plantations; we may also recommend the most efficient products that can be used in order to combat thisfungus.

\section{References:}

1. Comes I, Lazar al, Dracea A, Babes I, Hatman M (1977). Phytopathology.Didactic and pedagogical publishing house, Bucharest.

2. Dobrota G, Dobrota MA, Strimtu D, Cardei E (1991). Plum culture.Ceres Publishing House, Bucharest

3. Ghena N, Mihaescu G, Popescu M, Cireasa V, Godeanu L, Dobrota G (1977). Plum culture.CeresPublishing House, Bucharest.

4. Glišiæ I, Karaklajiæ-Stajiæ Ž, Paunoviæ SA, Lukiæ M (2016). Plum cultivars Zlatka and Pozna Plava (Prunus domestica L.) bred at the Fruit Research Institute in Èaèak. Hort. Sci. (Prague), 43: 10-16.

5. Gradinaru G, Istrate M, (2004). General and special fruit growing. Moldova-type publishing house, Iasi.

6. Labusca A V, Manoliu A, Oprica L, (2011). Influence of the attack of the fungus Polystigma rubrum (pers.) dc (red left spot) on nutritional value of fruits in different plum cultivars. Scientific Annals of "Alexandru Ioan Cuza" University, Genetic Section and Molecular Biology, 11: 139-146.

7. Lupescu F, (2005).Tree culture in the familygardens. CeresPublishing House, Bucharest.

8. Macuhova H, Briatkova V (1991). A survey of fungal diseases of plums, their spreading and protective measures. International information system for the Agricultural Science and Technology, 9: 57-74.

9. Mitre I, Mitre V, Buta E, Mitre I, Tripon A, Sestras , (2015). Reaction of some plum cultivars to natural infection with Taphrina pruni (Fuck.) Tul., Fusicladium Pruni ducomet and Tranzschelia pruni-spinosae persoon dietel. Agriculture - Science and Practice, 1-2: 93-94.

10. Molnár B, Varga M, Vámos A, Holb IJ, (2018). Incidence of two leaf fungal diseases in two plum training systems. International Journal of Horticultural Science, 24 (3-4): 15-17.

11. Minoiu N, Lefter G (1987). Diseases and pests of spiny species. Ceres Publishing House, Bucharest.

12. Oroian I, Florian V, Holonec L (2006). Atlas of trilingual phytopathology. The Romanian Academy Publishing House, Bucharest.

13. Parvu C (2002).Encyclopedia of plants. Plants from the flora of Romania. Vol I AC, Technical Publishing House, Bucharest.

14. Parvu M (2010). Practical guide to phytopathology. Publishing house Press Clujeana University, Cluj. 